\title{
Author Correction: Continuous moulting by Antarctic krill drives major pulses of carbon export in the north Scotia Sea, Southern Ocean
}

\author{
C. Manno, S. Fielding, G. Stowasser (D), E. J. Murphy, S. E. Thorpe (iD) \& G. A. Tarling (D)
}

Correction to: Nature Communications https:/doi.org/10.1038/s41467-020-19956-7, published online 27 November 2020.

The original version of this Article contained an error in the Discussion, which incorrectly read 'Assuming a krill population biomass of $379 \mathrm{Mt}$ for the Southern Ocean, we estimate that the exuviae flux can contribute a seasonally averaged mean of $0.29 \mathrm{t} \mathrm{C} \mathrm{d}-1$ (SE 0.09; see Supplementary Methods).' The correct version adds ' $M$ ' to the unit before ' $t$ C d-1'. The Supplementary Information file was also updated as one paragraph had many errors. These errors have been corrected in both the PDF and HTML versions of the Article.

Published online: 05 March 2021

\section{Additional information}

Supplementary information The online version contains supplementary material available at https://doi.org/10.1038/s41467-021-22037-y.

\footnotetext{
(i) Open Access This article is licensed under a Creative Commons Attribution 4.0 International License, which permits use, sharing, adaptation, distribution and reproduction in any medium or format, as long as you give appropriate credit to the original author(s) and the source, provide a link to the Creative Commons license, and indicate if changes were made. The images or other third party material in this article are included in the article's Creative Commons license, unless indicated otherwise in a credit line to the material. If material is not included in the article's Creative Commons license and your intended use is not permitted by statutory regulation or exceeds the permitted use, you will need to obtain permission directly from the copyright holder. To view a copy of this license, visit http://creativecommons.org/licenses/by/4.0/.
}

(C) The Author(s) 2021 